\title{
TEACHING OF INDIAN DRAMA THROUGH INNOVATIVE ACTIVITIES IN A CLASSROOM OF FOREIGN STUDENTS: THE NATURE OF TEACHER/PARTICIPANT COLLABORATION
}

\author{
Amara Khan \\ Assist. Prof. Dr., Lahore College for Women University, Lahore, PAKISTAN, \\ khanamara@gmail.com
}

\begin{abstract}
The teaching of drama is considered to be one of the most momentous and exciting areas in a classroom. Various innovative classroom activities can be used to make the teaching of drama enjoyable and enthralling. The practice of innovative classroom activities ascertains advantageous in a classroom where the students are not much accustomed to the dramaturge and her/his cultural experience. The manuscript puts forward various innovative classroom activities that can be used whilst teaching Indian drama to the undergraduates with foreign background. Girish Karnad is a notable Indian dramatist whose considerable works have suggestively added to the rich tradition of Indian theatre. The dramas are Karnad's courageous and effective experimentation on folk subjects. The present paper makes an endeavour to set forth innovative classroom activities for the teaching of Karnad's play, Hayavadana (1971). The innovative classroom activities enrich students' understanding and conception of the play. They stimulate students' curiosity and support them to contribute to the classroom activities. The innovative classroom activities nurture a spirited awareness of contribution by the students. In short, the innovative classroom activities encourage students to enthusiastically contribute in diverse classroom activities and gear up their scholarship. Hence the paper endeavours to confirm how the innovative classroom activities improve and strengthen students' understanding and appreciation of Karnad's Hayavadana (1971).The paper sets forward the inventive classroom activities that are particularly planned for teaching Karnad's Hayavadana (1971). The new classroom activities provide openings to instructors to teach the play ingeniously. They encourage independent and imaginative views on the part of students. They invigorate the discussion and motivate students' creativity and vision. The article incorporates a real evidence of the teacher-in-role approach and a dialogue. The approach of applied theatre has been employed in which the participants, jointly with the facilitator, participate in the co-construction of the story. As a theatrical practice, it reassures intercession of implication through the activity of skill and contemplation. In this exposé, I suggest on the nature of the concerted progression between teacher and participants, representing my involvement in Approaches to Theatre in Semester 1 at the University of Leeds, United Kingdom in 2014-2015. As my supervisor got Karnad's Hayavadna (1971) on the module and I was doing my PhD on Indian and Nigerian theatre, therefore, I was informally involved in the teaching lectures, seminars, and theatrical activities. I worked with three cohorts of undergraduate students from different parts of the world. I here draw on classroom records to show the central dramatic approach of the method: "teacher-in-role". I present the stratagem, situate it in a theoretical framework and discourse problems and suggestions when teaching is utilized to involve, rather than to feed.
\end{abstract}

Keywords: Classroom activities, foreign students, innovation, Girish Karnad, Hayavadana, teaching. 


\section{INTRODUCTION}

The teaching of Indian drama in a classroom of foreign students can be made efficacious and driving by exploiting innovative classroom activities. The paper sets forward the innovative classroom activities that were noticeably planned for teaching Girish Karnad's Hayavadana (1971). The innovative classroom activities offered opportunities to the teacher to teach the play inventively. The activities encouraged objective and imaginative view on the part of students and brightened the class and stimulated students' ingenuity (Wilson, 2017).

Participants with the instructor engaged in the co-construction of a theatrical domain. The atmosphere of the classroom was similar to Process drama which is a kind of applied theatre. The beginnings of process drama date back to the 1970s, when educationalists Bolton and Heathcote began to exercise and reproduce on what was then discussed as "drama in education" (Bolton, 1979). Educational drama as an experimental teaching was used to teach history, drama, and English in a range of didactic settings, chiefly primary and secondary contexts. In the 1990s, Cecily O'Neill set the basic foundations for teaching (O'Neill, 1995). O'Neill defines process drama as a thematic search, rather than isolated skits, where the result is not fixed, but revealed in course. But Process drama advances without a script, does not conclude in a closing act, and is characterised by the absence of external spectators. Each contributor (with the tutor) takes on diverse roles and become involved in the making of a story, undergoing a dramatic situation for educational commitments.

For the purpose of this research, I focused on the experiential phase, the vital part of the process drama teaching structure. During the experiential phase, I made use of dramatic strategies to organise the involvement. Presently there are over eighty known process drama approaches (Bowell and Heap 2001, Neelands and Goode, 2000); every convention has an unusual tenacity and can be used by the instructor to generate compassion, or aloofness, deference for a certain theme or dramatic setting.

Heathcote introduced the "teacher-in-role" approach (1973); it engages the teacher taking on a role in the drama and contriving beside the participants. It is an advanced academic stratagem which comprises a number of variations to conventional classroom arrangements of collaboration. Primarily, teacher-in-role comprises a status change: it reverses the Teacher/Students (T/STS) order of the usual, teacher-centred methodology, where the teacher may ask rhetorical questions to the students, encouraged to answer only when called upon. This necessitates the teacher to become alert that she/he is enacting a social responsibility as "teacher" in the classroom-environment, to intentionally step out of this role, and take on a different role. Through teacher-in-role, I chose to have a subordinate position than the participants, setting up a more motivating dynamic in terms of agency, influence, and power.

"Teacher-in-role" functions as a strategy for learning, as well as noteworthy philosophies of teaching (Kao and O'Neill, 1998). It is based on constructivist theories of education, according to which knowledge is not inactively transferred into students' heads, but each learner energetically constructs it. It is grounded on the notion of "cognition" not as an item positioned within the individual academic, but a process spread across the knower, the atmosphere in which knowing ensues, and the activity in which the student partakes (Barab and Squire, 2004, pp. 1-14). Process drama resonates with this view, as it believes "playing" as very useful for education. It approves Bruner's reason (1976) of "play" as a performance that curtails the effects of one's actions, delivering openings to attempt blends of new activities without worry or outer burden of accomplishment. During the experiential phase, students were inspired and exposed to reliable indexes of verbal and non-verbal communiqué; in the reflective phase, I steered students to reflect and study Indian theatrical techniques used in the drama.

I took on a character to resonate with Eisner's (1985) discussion on "teaching as an art." Eisner claims that teaching is an art conducted by educational morals, particular requirements and principles believed by the teacher. Echoing Dewey (1934), Eisner defines "art" as a process in which skills are employed to discover ends through action, as opposed to "craft" where skills are employed to arrive at preconceived ends. He advocates that artistry in teaching is important because the teacher who functions artistically provides learners with sources of aesthetic experiences that can foster exploration, risk-taking, and disposition to play (1985, p. 183).

One of the main concerns in teaching Indian drama was to provide learners with India's "real-life" experience. Felton et al. (1988) believe that compared to the informational exchange in an archetypal class, there is a developed part of interactional and open exchange when learners are involved in drama activities. It was observed that through drama, learners were keener to share their thoughts and interpretations with other learners in a protected atmosphere. Needlands (1992) recommends that if the tutor and learners are 
capable of using drama to produce roles and situations, there will be a superior assortment of diverse circumstances for dialogue. Experiential drama exposes learners to the use of language in different contexts and promotes greater abstract thinking on various issues. Rosen and Koziol, Jr. (1990) observed the connection of drama activities to the enhancement of verbal contact abilities, understanding, conception, and approaches. They recommend that offering learners with enjoyable and exciting energetic reading trials is imperative for teaching eloquence and comprehension (Jordan \& Harrell, 2000, pp. 73-80).

Presentational performance was introduced with the purpose to entertain, instruct, and persuade. It allowed learners to take practically a portion of text, study it and adjust it into a script. The script was then acted with minutest of arrangement, props or backdrop. It involved students in becoming empathetic towards their world, producing their own scripts, reading loudly, acting with determination, and conveying delight to both themselves and their spectators.

\subsection{The Research Question}

Although drama script performance has been adopted for use in classrooms in several educational venues, limited findings have been shown to discourse both its academic and instructive issues in the classroom of students with foreign background. Hence, the exploration for this analysis is steered by the following question:

"What are the perceptions of drama learners of the use of innovative theatrical techniques to improve their understanding of Indian drama written in English?"

\section{THE RESEARCH SETTING}

Indian drama was introduced to mixed culture learners enrolled in an English programme in the University of Leeds, United Kingdom for 2014-2015 academic session. The drama activity was conducted with three classes of First-year undergraduates registered with an English Literature Class. Each English session was comprised of 10 students.

\section{METHODOLOGY}

The data for this study was obtained through observation. In addition, the tutor's reflections were correspondingly used to triangulate the data. Throughout the drama activities, I jotted down notes and prepared comprehensive field notes on students' learning behaviours.

This course was designed to offer students with an understanding of the approaches and talents of specialized interaction, and train students to handle verbal and written communication undertakings in several settings. The foremost emphasis was on learning through involvement in class. Students learnt through a variability of means such as group discussion, enactment, and replication.

\section{CLASSROOM PROCEDURES}

The classroom activity was implemented in the following stages:

STAGE

\begin{tabular}{|l|l|}
\hline $\begin{array}{l}\text { One: Preparing students for } \\
\text { studying Indian drama for the } \\
\text { first time }\end{array}$ & $\begin{array}{l}\text { As a way to prepare students for understanding of Indian } \\
\text { drama by reading the text aloud. As students practice reading } \\
\text { aloud in groups of four or five, I explained the importance of } \\
\text { using only the voice elements to vary the pace of reading, } \\
\text { tempo, volume, and pitch to make the story "sound" more } \\
\text { interesting and natural. }\end{array}$ \\
\hline Two: Introducing the text & $\begin{array}{l}\text { I, along with the students, selected reading passages } \\
\text { relevant to class. I conducted a pre-reading activity (enquiring } \\
\text { and elucidating the terminology) to familiarize students with } \\
\text { the story. }\end{array}$ \\
\hline Three: Writing the script & $\begin{array}{l}\text { I provided a setup for the script writing. Students formed } \\
\text { groups and wrote a script grounded on a given situation that } \\
\text { we together highlighted. }\end{array}$ \\
\hline
\end{tabular}




\begin{tabular}{|l|l|}
\hline Four: Rehearsing the script & $\begin{array}{l}\text { I checked the script and students prepared the final draft after } \\
\text { discussion with me. }\end{array}$ \\
\hline Five: Performing the script & $\begin{array}{l}\text { Students executed the script in front of the class. A Readers } \\
\text { Theatre rulebook was used to evaluate students' act. I played } \\
\text { back the demo and encouraged students to comment on their } \\
\text { peers' enactment. }\end{array}$ \\
\hline
\end{tabular}

The results of part one of the observation show that a majority of students displayed positive attitude towards the workshop activity. In their responses to the first activity, majority of the students agreed that the lesson was more interesting with theatrical activities. The students also felt they became more confident understanding Indian drama through workshop theatre. When asked whether they liked collaborating with others in the drama activity, majority of the students said they enjoyed working with their friends in performing extracts. It is interesting to note that many of the students were motivated after watching their friends perform their scripts. Compared to previous lessons where the students normally maintained a passive stance in class discussions, the class was lively during the workshop activity.

Table 1: Categorization of Students' Statements on Workshop Theatre Activities

\begin{tabular}{|l|l|l|}
\hline Category & Subcategory & Feedback from Students \\
\hline $\begin{array}{l}\text { Attitudes towards } \\
\text { the Workshop } \\
\text { Theatre Activities }\end{array}$ & Selecting the Excerpt & $\begin{array}{l}\text { - the script writing was hard nevertheless pleasurable } \\
- \text { motivating as we could practice writing - could } \\
\text { appreciate what other students consider concerning } \\
\text { the topic - beneficial because it delivered opening to } \\
\text { converse around a subject related to personal lives }\end{array}$ \\
\hline & Rehearsing the script & $\begin{array}{l}\text { - the atmosphere was not boring - permitted students } \\
\text { to express their views if they were on stage }\end{array}$ \\
\hline & Performing the script & $\begin{array}{l}\text { Liked the activity as other script acts were exciting } \\
- \text { Inspired individual students after considering other } \\
\text { group members act. } \\
\text { - Entertaining to observe other groups' performance }\end{array}$ \\
\hline
\end{tabular}

\section{TEACHING OF DRAMA}

The teaching of drama in the classroom of foreign students is considered to be one of the most challenging tasks. It requires a great effort on the part of the teacher to design riveting and engrossing classroom activities that can stimulate learners' curiosity and arouse their attention in studying the play. The teacher has to assist students "...overcome the barriers posed by language" (Collie and Slater, 2009, p. 164) and to help them "... to a better understanding of a dramatic structure" (Collie and Slater, 2009, p. 164). The purpose of teaching drama is to "... improve students' comprehension" (Gurav, 2005, p. 41). Lazar (2009) notes that the teaching of drama has a larger didactic role in the classroom of foreign students. It helps to arouse the ingenuity of students, to advance their analytical skills and to intensify their emotive cognizance. When the teacher asks students to answer individually to the dramatic script, students become poised concerning articulating their notions and sentiments. Lazar (2009) further mentions that they "... feel empowered by their ability to grapple with the text and its language and to relate it to the values and traditions of their own society" (p. 19). Thus the aim of teaching drama is to assist students in comprehending and appreciating the dramatic text. 


\section{TEACHING OF GIRISH KARNAD'S HAYAVADANA (1971): A CASE STUDY}

The case study explained below took place in the department of English, University of Leeds, United Kingdom, where I facilitated drama, mixing diverse research methods. The participants in this case study had experience in European and American drama, but had no familiarity with Indian drama. I took observational notes, and partook in individual interaction with participants before and after the class. They moreover participated in a focus group at the completion of the drama intercession, where I used research strategy to generate discussion. I also used a kinaesthetic approach of interviewing, grounded on the props from the drama, as a trigger to stimulate discussion.

I focused on the purpose of "Teacher-in-Role" and on its implications on participants' engagement. My choice in taking the role of "the team director" was dictated by the circumstances that the group of students had never read any Indian drama earlier; as their first Indian drama, they required to be steered in the course. Nonetheless, there were countless methods of using role and position; one was through the attitudes of the role.

The celebrated Indian playwright Girish Karnad's illustrious play Hayavadana (1971) was chosen for the study under discussion. Karnad himself translated Hayavadana (1971), the play scripted in Kannada, into English. The paper offers varied innovative classroom activities for teaching Karnad's Hayavadana (1971). The paper claims that the innovative classroom activities enhanced students' appreciation and understanding of the play. The diverse classroom activities drew students' attention, excited their interest and accelerated their learning process. They provided the needed stimulus for the effective teaching of Hayavadana (1971)

\section{SIGNIFICANCE OF INNOVATIVE CLASSROOM ACTIVITIES IN THE TEACHING OF DRAMA}

"Despite all the innovations which have entered the language teaching profession in the wake of 'communicative revolution', it remains true that the vast majority of what happens in classrooms is... achieved by concentrated, effortful activities" (p. 3), notes Maley in his Foreword to Wilson's (2017) noteworthy book Drama and Improvisation. The innovative classroom activities indeed perform a noteworthy function in the teaching of drama. They enliven the drama class and activate "students' imagination and creativity" (Wilson, 2017, p. 5). They help students to "... deepen their understanding of the text and the dramatic situation" (Collie and Slater, 2009, p. 164). In brief, the innovative classroom activities enhance students' understanding of the dramatic text.

\section{STUDENTS' PARTICIPATION IN CLASSROOM ACTIVITIES}

In the teaching of drama the input of learners in the classroom activities is extremely important. The classroom activities enhance students' appreciation of the dramatic text. I, therefore, encouraged students to participate in classroom activities. It enhanced their interpretative skills. Thus the involvement of students in classroom activities is in fact a matter of great importance.

\section{INNOVATIVE CLASSROOM ACTIVITIES FOR TEACHING GIRISH KARNAD'S HAYAVADANA}

The teaching of Girish Karnad's Hayavadana (1971) was made interesting and engrossing by using innovative classroom activities. The innovative classroom activities designed for teaching Hayavadana (1971) are listed below:

a. Read the handout and note down the vital realities of Girish Karnad's life and his works.

In this activity students were given a handout which presented a short biographical sketch of Karnad. It provided them with the important facts of Karnad's life and introduced them with his works. It developed their reading skill and sub-skills namely skimming, scanning, and note-making.

\section{b. Draw the sociogram presenting the characters of the play.}

In this activity I drew a sociogram on the board. I familiarized students with different characters of the play and explained to them the relationship amongst them. This activity developed students' thinking and predictive skills.

\section{c. Read the play and participate in the discussion.}

In this activity I assigned different characters to the undergraduates and asked them to read the play. The 
reading of each act of the play was followed by discussion. The activity improved students' reading, listening, and speaking skills. After the reading of the acts students were encouraged to participate in the discussion about the characters, set, and plot of the play. These brainstorming sessions helped students to understand and appreciate the play. The reading of the acts enabled students to learn the proper pronunciation of Hindi words written in the text.

\section{d. Guess what would have happened if...?}

In this activity the undergraduates were divided into groups and every group was given an unlikely situation and probed to contemplate about the possibility of the situation. This activity made students reflect individually about the specified setting. It also helped them to advance their dialogue delivery talents as they discussed things among themselves. It helped students to employ their cognitive sub-skills such as foreseeing, predicting, and conjecturing from the framework, exploiting their earlier understanding (Ganpule, 2014, p. 174).

I. Padmini would not have swapped the heads of Devadatta and Kapila.

II. Kapila would have married Padmini.

III. Hayavadana would have become a complete human being.

IV. Devadatta and Kapila would not have killed each other.

V. Padmini would not have become a sati.

e. Fill in the grid with brief remarks

Grid 1: Elements of the play

\begin{tabular}{|lll|}
\hline Situation & Temporal & Genre \\
\hline Geographical & & \\
\hline Physical & Tone & Theme \\
\hline Plot & Rising Action & \\
\hline Main Plot & Climax & Major Conflict \\
\hline Subplot & Falling Action & \\
\hline Conventions and motifs of folk tales and folk theatre & \\
\hline
\end{tabular}

In this activity students were presented with a grid. They were asked to fill it with brief remarks. This activity helped the undergraduates to review the evidences that they had previously identified. It helped them to develop their writing skill. It helped them to organize their thoughts and ideas logically (Ganpule, 2014, p. 175).

\section{f. Hot-Seating: Choose a role-card, sit in the hot-seat and reply to the questions.}

In this activity the undergraduates chose a role-card from the given cards and the rest of the class became the interviewers. The role-cards that were offered to students were: 1) Devadatta 2) Kapila 3) Padmini 4) Hayavadana, and 5) Goddess Kali

This activity enabled the students to know the characters. It enhanced their speaking skills and thinking skills.

\section{g. Fill in the grid with appropriate responses.}

In this activity groups of three/four students were given grids with empty boxes and were asked to label the boxes with response prompts. They were asked to write down their responses and share their ideas. This activity improved students' thinking and writing skills. They exchanged ideas with peers and enjoyed the activity (Mayer, 2008, p. 15). 
Grid 2: Labelling the boxes with response prompts

\begin{tabular}{|l|l|l|}
\hline I consider that Padmini... & I believe Devadatta... & I value Hayavadana... \\
\hline I object Kapila... & $\begin{array}{l}\text { I consider the } \text { utmost } \\
\text { imperative action was... }\end{array}$ & I support Padmini... \\
\hline I detest Padmini... & I approve Hayavadana... & One thing I enjoy the most... \\
\hline I regard Kapila... & In my belief Devadatta... & I feel bad about the child... \\
\hline
\end{tabular}

\section{h. Watch the performance of Hayavadana and write a review of the performance of the play in the} light of the following topics: a. Set b. Music c. Props d. Actions e. Costumes f. Light

In this activity the theatrical performance of Hayavadana, available on YouTube, was screened and then students were asked to write an evaluation of the performance of the play in the light of the specified topics. The activity enhanced students' thinking and writing skills (Ganpule, 2014, p. 64).

The following are the links of the performance of the play Hayavadana (1971):

(https://www.youtube.com/watch?v=1KeVbHYX8yM)

(https://www.youtube.com/watch?v=vCV2NcHKQoE)

(https://www.youtube.com/watch?v=1KeVbHYX8yM)

Thus the innovative classroom activities given above were used while teaching Hayavadana (1971).

\section{DIFFICULTY LEVEL OF CLASSROOM ACTIVITIES}

The classroom activities designed for teaching Karnad's Hayavadana (1971) were varied and diverse. They differed in their level of difficulty. Some classroom activities were elementary and simple and some others were complicated and demanding. Students could effortlessly work out the easier classroom activities. On the other hand difficult classroom activities required great effort on the part of students. There were also some classroom activities which were moderate in their level of difficulty. They were neither excessively difficult nor extremely easy. The miscellany of classroom activities exhibiting variant levels of difficulty excited students' curiosity and engaged their interest.

\section{CLASSROOM OBSERVATION BY THE TEACHER}

A lot of discussions on Indian drama were observed during the workshop activity as individual students were keen to express their own interpretations on the script. Through the workshop activity, students were able to communicate their views to explore roles, ideas, and characters as they worked on the performance task. In the process, they learnt to use language in order to expose distinctive characters and settings. The negotiation of meaning allowed students to practice different aspects of the drama as much as possible. In addition, students' understanding of the Indian drama was enhanced through the negotiations of script. The class was lively and enjoyable as students rehearsed and performed the scripts for other students.

\section{CONCLUSION}

The present paper put forth innovative classroom activities for teaching Karnad's Hayavadana (1971). The innovative classroom activities aroused students' interest and augmented their understanding of the play. They assisted students in analyzing the play and interpreting the varied themes of the play. The use of innovative classroom activities made the teaching-learning experience enjoyable for both the teacher and students. As a result, the intricacies and complexities in the plot-structure of Hayavadana (1971) were no longer inscrutable to students. They comprehended the play in its entirety.

I have discussed here the inventive collaboration involved between facilitator and participants, and the fundamental philosophies of creativeness upon which it is constructed. I have argued that the improvisation entails the teacher-in-role to work as a teacher-artist. I have also highlighted how the Workshop theatre practice offers productivity and liveliness in the drama classroom because students are experientially involved in performing a piece of literature. As an outcome, they become involved and advance a sense of investing in the lesson because they are not only performing an academic assignment but also learning how 
to communicate their ideas on a topic relevant to their lives. In order to carry out drama activity effectively in the classroom, appropriate involvement in directing group activity is necessary. The accomplishment of the activity primarily depends on the teacher's clear directions to the students. The teacher must confirm that all students are involved to produce enough characters involving the subject. The teacher also needs to incorporate the function of a narrator and stress the importance of a good narrator in setting the atmosphere of the play. A narrator can present the subject or theme for the script. For instance, for a script performance about conflicts in Hayavadana, the narrator can provide the following introduction to the performance:

Have you ever been involved in a conflict? What can you do to resolve a conflict? Today, our performers will tell you more about conflict.

It is also necessary that a teacher should permit students enough time to rehearse and review their script. The teacher should allow students flexibility on roles in case they do not work out. In addition, students should be able to contact the teacher should they face difficulties in elocution, pitch, emphasis, and other theatrical requirements. The teacher should also note that there could be limitations to study Indian drama in the classroom especially when students have no familiarity with Indian culture and theatre. In addition, the benefits of comprehension, cooperation, and responsibility should be taken into consideration more.

\section{REFERENCE LIST}

Barab, Sasha, Squire, Kurt (2004). Design-Based Research: Putting A Stake In The Ground. The Journal of the Learning Sciences 13/1, 1-14.

Bolton, Gavin (1979). Towards A Theory Of Drama In Education. London: Longman.

Bowell, Pamela, Heap, Brian (2001). Planning Process Drama. London: David Fulton.

Bruner, Jerome S., Jolly, Alison; Sylva, Kathy (eds.) (1976). Play: Its Role In Development And Evolution. New York: Penguin Books.

Collie, J., Slater, S. Literature in the Language Classroom, New Delhi, Cambridge University Press.

Dewey, John (1934). Art As Experience. New York: Perigee

Eisner, Elliot W. (1985). The Educational Imagination: On The Design And Evaluation Of School Programs. New York: MacMillan.

Felton, M., Little, B., Parsons, and Schaffner, M. (1988). Drama, Language and Learning. NADIE Paper No.1. Australia: National Association for Drama in Education.

Ganpule, S. "Use of Task Based Activities in the Teaching of Drama," International Journal of Human Movement and Sports Sciences, vol. 2 (4), pp. 59-67.

Gurav, H.K. (2005). Aspects of English Language, Pune, India, Nutan Prakashan.

Heathcote, Dorothy (1973). Drama As Challenge. In: Lambert, Johnson; O’Neill, Cecily (eds.): Dorothy Heathcote, Collected Writings of Drama and Education. London: Hutchinson.

Jordan \& Harrell. (2000). Readers Theatre: A Creative Tool for Strengthening Skills of Emergent Readers. Kindergarten Education: Theory, Research and Practice, 5 (73-80).

Kao, S. (1994). Classroom Interaction in a Drama-oriented English Conversation Class of First-year College Students in Taiwan: A Teacher-researcher study (Chinese Text). Unpublished doctorate dissertation, The Ohio State University, USA.

Kao S. \& O'Neill, C. (1998). Words into Worlds: Learning a Second Language through Process Drama. Stanford: Ablex Publishing Corporation.

Kao, Shin Mei, O’Neill, Cecily (1998). Words Into Worlds: Learning A Second Language Through Process Drama. London: Ablex Publishing Corporation.

Karnad, G. (2005). Hayavadana. In: Collected Plays: Volume 1, Oxford, Oxford University Press.

Lazar, G. (2009). Literature and Language Teaching, New Delhi, India, Cambridge University Press. 
Mayer, L.R. www.youtube.com/static/pdf/teachersguide/Dollshouse T.G.pdf.

https://www.youtube.com/watch?v=1KeVbHYX8yM: Retrieved on 5 July 2015 at $09.51 \mathrm{am}$.

https://www.youtube.com/watch?v=vCV2NcHKQoE: Retrieved on 5 July 2015 at $09.53 \mathrm{am}$.

https://www.youtube.com/watch?v=1KeVbHYX8yM: Retrieved on 5 July 2015 at 10.00am.

Needlands, J. (1992). Learning through Imagined Experience. London: Hodder and Stoughton Educational.

Neelands, Jonothan, Goode, Tony (2000). Structuring Drama Work: A Handbook Of Available Forms In Theatre And Drama. Cambridge: Cambridge University Press.

O’Neill, Cecily (1995). Drama Worlds: A Framework For Process Drama. Portsmouth: Heinemann.

Wilson, K. (2017). Drama and Improvisation. Oxford, Oxford University Press. 